This is an Accepted Manuscript version of the following article, accepted for publication in Transport Reviews. Franziska Kirschner \& Martin Lanzendorf (2020) Parking management for promoting sustainable transport in urban neighbourhoods. A review of existing policies and challenges from a German perspective, Transport Reviews, 40:1, 54-75, DOI: 10.1080/01441647.2019.1666929. It is deposited under the terms of the Creative Commons AttributionNonCommercial License (http://creativecommons.org/licenses/by-nc/4.0/), which permits non-commercial re-use, distribution, and reproduction in any medium, provided the original work is properly cited.

\title{
Parking management for promoting sustainable transport in urban neighbourhoods. A review of existing policies and challenges from a German perspective.
}

The organisation of parking is a key challenge to more sustainable mobility in urban areas, as its pricing and availability affect the rates of private car ownership and use. However, changing parking policies is a challenging issue for local politicians and planners because residents frequently oppose changes or restrictions to conditions they have taken for granted such as on-street parking in a public space. The aim of this paper is firstly to assess how the parking policy of an urban neighbourhood can be structured to contribute to more sustainable mobility and to increase liveability in the neighbourhood. The second aim is to apply the policies reviewed to an example neighbourhood. For this purpose, we systematically reviewed academic literature and identified five types of relevant parking policies: (i) maximum parking requirements, (ii) physical detachment of residence and parking space, (iii) residential parking permits and the limitation of available parking space, (iv) performance-based pricing and (v) parking as a demand management strategy. We discovered that most research focuses on econometric models about parking and that studies rarely address the effects of parking on the quality of life in neighbourhoods. Therefore, we need further research regarding the relationship of parking and liveability. We conclude that for the implementation of such parking policies in an example neighbourhood, the municipality needs to develop a mobility vision for its city. It has to understand parking as a tool for transportation demand management to increase the acceptance of parking policy concepts and to avoid spillover problems. Finally, in the German case, as in most other countries, states and municipalities need to redesign their legal frameworks to be able to manage parking supply better and to react to changes related to digital developments and parking. The findings have implications for other European neighbourhoods regarding the transfer from research to local circumstances and applications for the whole city.

Keywords: parking policy; parking management; residential parking; Frankfurt; sustainable mobility 


\section{Introduction}

Private cars are parked for 23 hours a day on average and for most of that time vehicles stand at residential parking sites (Marsden, 2014; Shoup, 2005). Despite car parking's high share of land use in urban areas and its role as an important motivator for car ownership and use, rethinking urban parking policies challenges planners and politicians, as it is frequently contentiously discussed at local level. Furthermore, digital developments offer improved opportunities for mobile parking systems or time-spatially differentiated pricing and thus contribute to new discussions. Parking appeared on the agenda of the broader society in Germany and Frankfurt recently when the Hessian state administrative court ruled that the city of Frankfurt should consider extensive parking regulations to incentivise the use of public transport in the city, in addition to driving bans for diesel vehicles (VG Wiesbaden, 2018). With its decision, the court did not only rule on the driving bans, but recommended transportation demand management (TDM) instruments for a more sustainable transport policy.

Today, virtually all European cities have parking regulations that shifted slowly from 'predict \& provide' to a 'travel demand management' policy (Mingardo, Van Wee \& Rye, 2015). Regulations and the management of parking are crucial for the future of urban transport because almost every car trip begins and ends in a parking area. For the 'system of automobility' (Urry, 2004) to work, a car needs four parking spaces of twelve square metres each on average: one at the owner's home and three others at destinations such as the workplace or the supermarket (Marsden, 2014; Shoup, 2005). Therefore, car traffic has a much higher need of urban space than public transport and non-motorised traffic (Apel et al., 1995). Lehmbrock (2000) and Litman (2016) estimate a car's land use to be even higher at 20-30 square metres when accounting for entrance space for a car park and shunting areas. Thus, Marsden (2014) refers to parking as one form of public 
land use that competes with other land uses such as housing or bicycle and pedestrian infrastructure and Knoflacher (2006) concludes "private parking places are destroying the living space of cities" (p. 397).

Regarding quality of life, most inner city neighbourhoods in European cities were built before the advent of the car and before the introduction of parking requirements. Usually, they have high population densities, a rich mix of functions, good access to public transport and low motorisation rates (Apel et al., 1995; Marsden, 2014). Often, streets of inner city neighbourhoods are an important open space for residents and an arena for interaction and communication (Notz, 2017). The decline of green space in favour of parking in neighbourhoods reduces beneficial health effects associated with greenery (e.g. Khreis et al., 2016). Moreover, the construction and maintenance costs of parking space are usually included in rental or retail prices. This increases the costs for housing and other products independently of one's car ownership and need for parking space (Shoup, 2005).

Marsden $(2006,2014)$ concluded in his review papers that more research in residential parking is necessary to understand the effects of parking on urban accessibility and attractiveness better. However, the reviews do not evaluate the potential of parking policies for sustainable mobility or liveability. Consequently, the objective of this review paper is firstly to assess how the parking policy of an urban neighbourhood can be structured to contribute to more sustainable mobility and to increase liveability in the neighbourhood. The second aim is to apply the policies reviewed to an example neighbourhood. We used the inner-city and densely populated neighbourhood of Frankfurt-Bornheim as one example of an urban neighbourhood where the use of alternative means of transportation could potentially be increased. Therefore, our aim is to answer the following two questions: (i) Which parking policy options do exist and what 
is known about their expected as well as evaluated impacts for more sustainable mobility and increased liveability in urban neighbourhoods? (ii) What challenges might arise for the realisation of parking policies in an example German neighbourhood (a) in regard to the national legal framework, (b) related to local implementation and (c) concerning new digital developments? We focus on European neighbourhoods that are highly urbanised, usually in close proximity to the city centre and which were developed before the era of mass car ownership (Marsden, 2014; Rye \& Koglin, 2014).

The paper is structured as follows: In section 2, we introduce the material by showing how we selected the chosen papers and introduce the German perspective on parking as well as our example. In section 3, we review existing policy concepts for urban areas and their impacts on sustainable urban mobility. We discuss the policy implications for Frankfurt-Bornheim in section 4 and in section 5 we draw some conclusions.

\section{Materials and Data}

\subsection{Selection of relevant literature}

For the selection of relevant literature, our goal was to find academic studies relating parking to sustainable mobility and liveability in urban neighbourhoods. We searched for articles in English and German with the keywords parking and residential parking in the databases Web of Science and ScienceDirect from the last twelve years since Marsden's (2006) first review. Second, we searched for the references of these articles related to the

research questions and we continued with this backward snowballing method several times (Jalali \& Wohlin, 2012) until the most relevant articles cited were in our database. After these two steps, our database contained around 100 articles, broadly connected to the research question. 
For the purpose of this review, we assess parking in urban, residential neighbourhoods from a municipality's or a user's perspective and discuss parking concerning sustainable mobility and quality of life. We identified 14 articles that connect parking in urban neighbourhoods with sustainable mobility (table 1). As we were focusing on the situation in European neighbourhoods, we tried to include research with a European context only. This appeared to be difficult, however, because many researchers conduct their analysis in the United States, for instance, regarding the SFpark concept of San Francisco (e.g. Chatman \& Manville, 2014; Pierce \& Shoup, 2013). Therefore, we incorporated those non-European studies that we found to be applicable to a European context because they discuss urban neighbourhoods with similar features, such as high density, parking pressure and extensive public transit supply, or those that touch upon issues which other studies consider only marginally.

For the selection, we defined three criteria of studies that would not meet the scope of this paper. First, we excluded studies that only calculate how to decrease the externalities of parking, but do not relate this to sustainable mobility. However, we discovered that most papers published regarding parking work with econometric models. Usually, such economic studies try to calculate how to reduce the externalities of parking, for example cruising (Inci, 2015). For instance, they analyse the costs of cruising and the welfare loss from this as well as residents' willingness to pay for a parking permit (Van Ommeren, Wentink \& Dekkers, 2011) or simulate a parking garage's operating day to assess the garage's turnover and queuing times (Caicedo, 2012). Second, as our focus is on residential parking, we did not include studies about workplace parking and workplace parking levies only (e.g. Dale, Frost, Ison, Nettleship \& Warren, 2017; Rye, Cowan \& Ison, 2006). Third, we excluded studies that solely focus on downtown parking or park- 
and-ride parking (e.g. Parkhurst \& Meek, 2014; Van der Waerden, Timmermans \& Da Silva, 2015).

Besides this, to the best of our knowledge, most studies do not incorporate other users of public space than car drivers and only few research articles address parking in combination with the quality of life in a neighbourhood. That is why we do not cover this issue in detail in chapter 3 but when we draw conclusions for the example neighbourhood in chapter 4.

\subsection{The German perspective on residential parking}

\subsubsection{National legal framework}

In Germany, the federal road traffic regulations act (Straßenverkehrsgesetz, StVG) and the federal road traffic act (Straßenverkehrs-Ordnung, StVO) regulate the parking of vehicles in public spaces. Regarding off-street parking, since the end of the 1930s, builders usually have to prove sufficient parking space when constructing or remodelling physical structures. Nowadays, each state has valid reference numbers to determine the demand and it is possible to provide a reduced number, for instance, when a parking space serves multiple user groups. Originally, the purpose of the regulation was to relieve public street space with floating traffic from parked vehicles (Apel et al., 1995; Lehmbrock,

2000). Consequently, the obligation to build sufficient parking space follows the idea of the traffic generation principle: The one who causes additional parking space demand has to comply with the demand on his/her own property (Heinrichs \& Schreiber, 2016).

\subsubsection{State level (Bundesländer)}

The road acts of the states (Straßengesetz, StrG) and the states' building codes (Bauordnung) contain further regulations about the construction of parking space, 
whereas detailed regulations are mentioned in the parking regulations (Stellplatzsatzung) of local municipalities (Apel et al., 1995; Heinrichs \& Schreiber, 2016). Our example neighbourhood in this review, Frankfurt-Bornheim, is located in the state of Hesse and, since 1981, the Hessian building code (Hessische Bauordnung, HBO) has included the possibility of restricting or prohibiting the construction of parking space for parts or the whole area of a municipality. The HBO therefore allows reduced construction of parking space if the builder can prove instruments with which the demand for parking space is reduced (e.g. public transport stations close by or the availability of carsharing vehicles ${ }^{1}$ ). In such cases, an exemption fee needs to be paid by the builder (Apel et al., 1995). Additionally, the obligation to provide bicycle parking space was established in Hesse's building code in 1990 and occurs if a municipality issues a clause accordingly (Land Hessen, 2018a; Lehmbrock, 2000). From June 2019 onwards, the HBO will also regulate the number of bicycle parking spaces that have to be provided (J. Woebbeking, personal communication, November 30, 2018).

\subsubsection{Municipal level}

At local level, since 1993, Hessian municipalities have made independent decisions about the obligation for parking spaces. Within the legal framework, municipalities have freedom of choice about any regulations, i.e. reduction, waiver and withholding of parking space. Still, reducing the amount of obligatory parking space has to be compensated by paying an exemption fee because a reduction without an exemption fee is only possible when parking space cannot be provided due to local circumstances. The amount of exemption fees usually depends on the average construction costs of a parking

\footnotetext{
${ }^{1}$ We understand carsharing as "short-term auto access" (Shaheen \& Cohen, 2007, p. 81).
} 
space, whereas Frankfurt has fixed rates. Furthermore, municipalities are allowed to use exemption fees for specific purposes only, for instance, for financing investment in public transport and bicycling (Land Hessen, 2018a; Lehmbrock, 2000).

\subsection{Case study of Frankfurt-Bornheim}

For the case study, we selected the existing neighbourhood of Frankfurt-Bornheim. It is located in the inner city district of Frankfurt and is a neighbourhood with one of the highest population densities in the city (City of Frankfurt, 2013; City of Frankfurt, 2018). The neighbourhood consists of a variety of building structures, such as an old town centre, Wilhelminian blocks (figure 1), large housing estates from the 1960s and recent housing developments as in many European neighbourhoods. While in Germany every fifth household does not own a car, in Frankfurt-Bornheim 40\% of households live without a private car (Infas \& DLR, 2018; own unpublished dataset, 2018). The neighbourhood has cycling infrastructure and carsharing stations. In addition, it is well served by public transport with several bus and tram lines running through the neighbourhood and linking it to adjacent areas. Moreover, four subway stations throughout the neighbourhood connect it to the central station within ten minutes (figure 2). In Frankfurt, one third prefer the car and another third use public transit or cycle. Compared to the whole country, Frankfurt has a lower share of car users and a higher amount of people using alternative means of transportation (Infas \& DLR, 2018; SrV, 2013). 


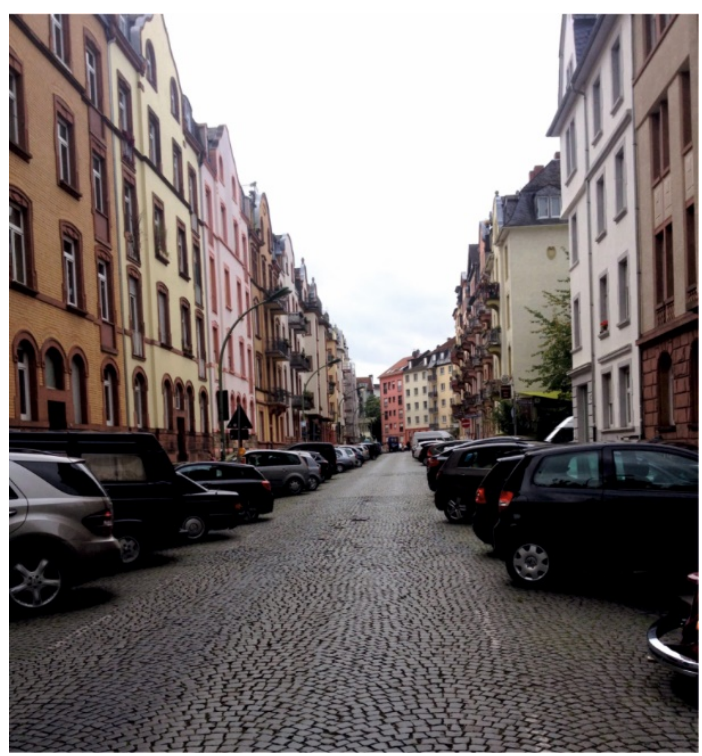

Figure 1. Residential street in Frankfurt-Bornheim. Own photograph, 2018.

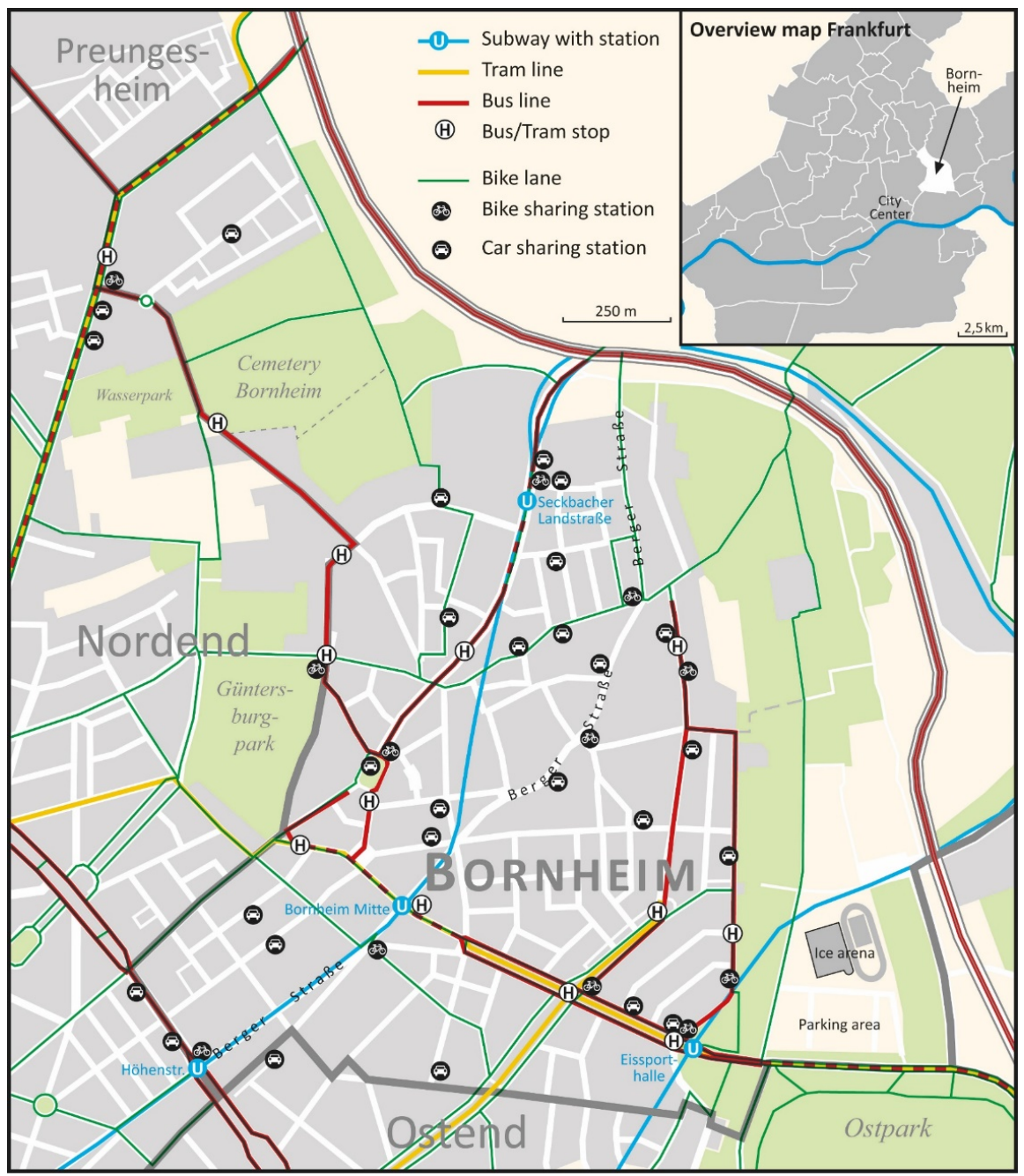

Figure 2. Map of location and mobility supply in Frankfurt-Bornheim. Design: Elke Alban. 
Frankfurt's parking space regulation requires obligatory parking space for new developments (City of Frankfurt, 2016). The regulation does not contain maximum parking requirements and, consequently, it still mandates minimum requirements. When a builder provides a reduced amount of parking space, $25 \%$ or $50 \%$ of the required parking space, depending on the area of the city, still has to be provided. Therefore, besides disabled parking and the development of subsidised housing, there can be no housing development without any off-street parking space in the city of Frankfurt with its current parking regulations.

A main component of on-street parking management is residential parking permits. Each municipality decides about them independently (Dümmler \& Hahn, 2011). Usually, a certain amount of parking space is reserved for certain user groups (residents, deliveries, people with disabilities), while for the remaining parking space temporal limits and a pricing scheme exist (Apel et al., 1995; Lehmbrock, 2000). The administrative regulations of the federal road traffic act and a court decision in Frankfurt regulate areas with residential parking permits. A maximum of 50 percent of all public parking spaces are reserved between 6 am and $10 \mathrm{pm}$ on weekdays and 75 percent are reserved during the night for parking permit holders. The remaining public parking spaces need to be freely available (VG Frankfurt am Main, 2004). Residents can receive a residential parking permit if they have proof of their first permanent residence, the car's permit and pay an administration fee. The fee amounts to $50 €$ for two years (City of Frankfurt, 2019). Yet, due to the principle of equality, the number of licenses for residential parking permits is not limited to the amount of licensed parking spaces. Hence, a license for a permit does not include a claim to a parking space, but only signals a privilege. As of autumn 2018, residential parking permits are only available in the southern part of the case study, while in all other areas of the neighbourhood on-street parking is free and without any time 
restrictions. Currently, the city is developing a new regulation for the whole neighbourhood, however, with residential parking permits and time as well as pricing restrictions (J. Woebbeking, personal communication, November 30, 2018). Finally, the city of Frankfurt had planned to introduce mobile parking payment systems as a pilot project in autumn 2018, but this has still not been implemented (Leclerc, 2017, 2018).

\section{Urban parking policies for sustainable transport}

From the literature review, we derived five parking policy concepts for urban neighbourhoods, which we present in this section (table 1): (i) maximum parking requirements, (ii) physical detachment of residence and parking, (iii) residential parking permits and the limitation of available parking space, (iv) performance-based pricing and (v) parking as a demand management strategy.

\subsection{Maximum parking requirements}

Maximum and minimum parking requirements are a tool for municipalities to regulate the provision of parking space for new developments. While with minimum requirements the builder must provide a certain amount of car parking, maximum requirements determine the maximum amount of parking per unit. Antonson, Hrelja \& Henriksson (2017) analysed the consequences of a land use policy shift with relatively restrictive parking requirements in a newly built residential area in Gothenburg, Sweden, with good access to public transport. Parking requirements in the case study are lower than in other areas of the city and the number of households with cars is the lowest in the whole city. The authors discovered that car ownership and car use stayed the same for the majority of residents before and after moving to the case study area. However, about 20 percent use public transport more and walk more often than before the move. While around half of the residents did not change their driving habits, one quarter drives a car less frequently 
and one fifth of new residents have access to fewer cars since the move, which they relate to the parking supply. Few interviewed residents connected their car ownership and use with the access to parking, however, and instead emphasised access to public transport and the centrality of the area.

Similarly, Christiansen, Engebretsen, Fearnley \& Usterud Hanssen (2017) detected that not having a dedicated parking space at home is one of the main factors that reduce the likelihood of using a car. Moreover, after controlling for sociodemographic and contextual factors, the likelihood of driving is reduced significantly as well when parking availability is limited both at the start and at the end of a trip.

Likewise for New York City, Weinberger, Seaman and Johnson (2009) indicate that, when comparing otherwise similar neighbourhoods, on-site residential off-street parking and ease of parking access contribute to a higher share of downtown car commuters from the neighbourhood with such parking features. Following these outcomes, Weinberger (2012) showed a relationship between guaranteed residential offstreet parking and an increased likelihood to use the car for commuting because areas with high levels of off-street parking have a higher level of car commute to the city centre.

In 2004, local authorities in the Greater London area shifted from minimum offstreet parking standards to maximum off-street standards for all new developments, which is part of a national UK agenda for transforming transport policy-making. Guo and Ren (2013) examined the parking supply of new residential developments before and after the introduction with data from the London Development Database. They discovered that supply was reduced by approximately $40 \%$ and most developers provide less than the maximum allowed. However, more parking was provided in areas with the highest density and best public transport services because in those areas parking provides a high revenue for developers. 
As regards policy implementation in the Netherlands, Van de Coevering and Snellen (2008) discuss three options complementing maximum parking requirements: First, discourage car ownership by introducing controlled parking zones with limited parking permits and simultaneously provide alternatives to the private car. Second, optimise the use of existing parking space to reduce total space necessary for parking because parking facilities are often only accessible for one user group such as workers or supermarket customers. Third, create more parking space in garages to generate a more efficient use of on-street parking space.

Guo and Ren (2013) conclude that complementary policies are necessary to avoid spillover effects, i.e. on-street parking controls, parking permits and parking pricing. Subsequently, maximum parking regulations are only effective if a municipality controls all submarkets, such as driveways and on- and off-street parking. Guo (2013a) argues that any kind of parking must be neither free nor freely available and Dümmler and Hahn (2011) go even further by criticising the obligation to provide parking space in general because it encourages car use.

Finally, on the one hand, Antonson et al. (2017) question whether changes in car ownership and car use depend on the residents' travel habits and the location of the area connected to public transport, rather than on parking requirements. Christiansen et al. (2017), Weinberger et al. (2009) and Weinberger (2009), on the other hand, conclude that maximum parking requirements are an important tool for influencing travel behaviour. The studies reviewed reveal that there is a relationship between the availability of parking at home and car use patterns. Moreover, municipalities may use maximum parking requirements even more efficiently by coupling the regulation with other instruments like parking permits, parking pricing (next sections) and effective controls. 


\subsection{Physical detachment of residence and parking}

Maximum parking requirements regulate the amount of parking space but not its specific location. However, even a maximum standard can be too high if it is labelled as a maximum, but rather works like a minimum standard (Guo \& Ren, 2013). Weinberger et al. (2009) criticise off-street parking provided as part of the property of a development because it makes a prepayment towards car ownership. Therefore, Knoflacher (2006) proposes a reorganisation of parking provision in urban areas by allowing parking solely in garages that are no better accessible than public transport stations at any origin and destination. The author argues that the likelihood for car use is higher if the walking distance to the parked car is shorter than to the next public transport station. In other words, the private car will lose its attraction if it is parked further away than the public transit station. Furthermore, in such a system, the minimum monthly price for parking should be at least the same as the price for a season ticket for public transport. Such a system would produce additional revenue to support further investments in the infrastructure for public transport, pedestrians and cyclists.

Recently, with data from the Norwegian National Travel Survey and additional in-depth interviews, Christiansen, Fearnley, Usterud Hanssen \& Skollerud (2017) showed that access to reserved parking space at home triples the likelihood of car ownership. Furthermore, car owners with reserved parking space less or more than 50m away from home have similar trip frequencies but different mode choices. Households parking more than 50m away make significantly fewer trips by car and significantly more on foot and using public transport. In addition, the likelihood of car use decreases with increased distance between home and the residential parking space and, simultaneously, additional reserved residential parking space increases the likelihood of car use. 
In conclusion, the literature illustrates that the physical separation of residence and parking space can reduce car use. Thus, for an increased use of more sustainable mobility, the distance between residential parking and homes should be at least the same as the distance between the nearest public transport station and residences.

\subsection{Residential parking permits and the limitation of available parking space}

Apart from private parking, municipalities often offer residential parking permits in innercity neighbourhoods. To manage the permits, Dümmler and Hahn (2011) recommend municipalities develop a strategic citywide parking management concept before implementing a residential parking zone. Mintsis, Taxiltaris, Basbas \& Stathis (2016) suggest municipalities be aware that convenient parking space reduces the likelihood of switching to more environmentally friendly modes of transport. In addition, the authors conclude that fees for parking permits and proof of no private parking space before issuing permits could be options to reduce the convenience of the permits. Moreover, municipalities should invest in marketing for car-free living for new residents and in the establishment of further instruments to influence mode choice and to reduce parking demand and land use (Dümmler \& Hahn, 2011; Mintsis et al., 2016). For example, a residential parking permit was introduced in Thessaloniki, Greece, in 2007 in two different zones in the city. It is free of charge, yet the permit does not guarantee a parking space because more permits are issued than there is available parking space. A survey with parking permit holders reveals that the educational level and time spent searching for parking affect the willingness to pay for the permit the most (Mintsis et al., 2016).

In conclusion, residential parking permits are foremost a reorganisation of access to parking space in residential neighbourhoods. Parking permits use the same amount of public space as without permits and give ease of access to residents. Still, if permits aimed at reducing the overall amount of parking space or were issued for off-street parking, they 
would be an instrument that regulates the available public space and restricts access to parking for non-residents.

\subsection{Performance-based parking pricing}

As residential parking permits are usually free of charge or cheaper than parking as a nonresident, several authors studied pricing schemes in relation to sustainable mobility. On the one hand, Ottosson, Chen, Wang \& Lin (2013) suggest that an ideal pricing policy should vary by time of day and by location, either block or neighbourhood-wise. Axhausen, Chikaraishi \& Seya (2015), on the other hand, stress that investments in public transport could work better as an incentive for mode shift than pricing parking, which can be funded by revenue from parking pricing management. Eventually, Van de Coevering \& Snellen (2008) expect that a pay-per-use principle (the higher a household's car ownership level, the greater the parking costs) increases awareness of the actual costs of parking space and demonstrates the importance of communication as part of mobility management for municipalities.

For example, spatially and temporarily varying parking fees already exist in Hiroshima, Japan. Moreover, before being allowed to buy a car, potential car owners have to prove their ownership or lease of a parking space (Axhausen et al., 2015). To understand how on-street parking demand responds to changes in pricing and how it can be adjusted to achieve a desired occupancy level, Ottosson et al. (2013) studied neighbourhoods in the downtown area of Seattle. The city of Seattle introduced a parking rate change in 2011 based on performance-based pricing with varying spatial and temporal prices. The results show that occupancy varies by time of day and neighbourhood characteristics and that parking fees affect the duration of stay. Besides this, the findings illustrate that increased parking fees in areas with good access to public transport encourage the use of public transport and other alternative modes. 
To conclude, parking fees may increase the awareness of on-street parking as public space. The implementation of performance-based pricing can be one instrument for municipalities to discourage the use of private cars in areas that are well served by public transportation. Furthermore, revenues from parking fees may be used to help fund alternative means of transportation.

\subsection{Parking as a transportation demand management strategy}

To understand parking as a TDM strategy implies that the former policy concepts reviewed are part of such a strategy because it incorporates a comprehensive approach for more sustainable urban mobility. Results from the household travel survey by the New York Metropolitan Transportation Council indicate that a reduced number of off-street parking spaces decreases the likelihood of owning one or more cars. Moreover, a reduced supply of on-street parking decreases car households' likelihood to own cars as well (Guo, 2013a). Furthermore, Guo (2013b) compared households with the same car ownership level but different parking access. He revealed that the households with off-street parking supply used public transport less often and have a higher car trip frequency than those households with solely on-street parking access. Thus, the literature suggests that a comprehensive approach towards parking is necessary to contribute to more sustainable mobility: (i) a citywide parking strategy and (ii) the incorporation of the neighbourhood's surrounding area. First, regarding the city's strategy, a parking policy needs to be considered as an integral part of transport policies and therefore it should fit into the broader transportation strategy of a city (Christiansen, Engebretsen et al., 2017; Van de Coevering \& Snellen, 2008). Besides the structural implementation, the studies reviewed suggest integrated thinking about parking policy and planning between different departments of a municipality as well as the inclusion of residents and stakeholders in the decision-making process for acceptance of projects (Antonson et al., 2017; Mintsis et al., 
2016). Second, many authors stress the inclusion of adjacent streets and neighbourhoods and their parking controls. Especially when building a neighbourhood garage with high tariffs, the surrounding areas need to be included in the parking management to avoid spillover effects (Antonson et al., 2017; Christiansen, Fearnley et al., 2017; Guo, 2013b; Guo \& Ren, 2013; Van de Coevering \& Snellen, 2008).

In conclusion, the literature reveals that an extensive strategy towards the management of urban parking is necessary. Studies indicate that parking supply is important for car ownership and that convenient residential parking encourages car usage. 
Table 1. Overview of selected literature regarding parking in urban neighbourhoods to foster more sustainable mobility.

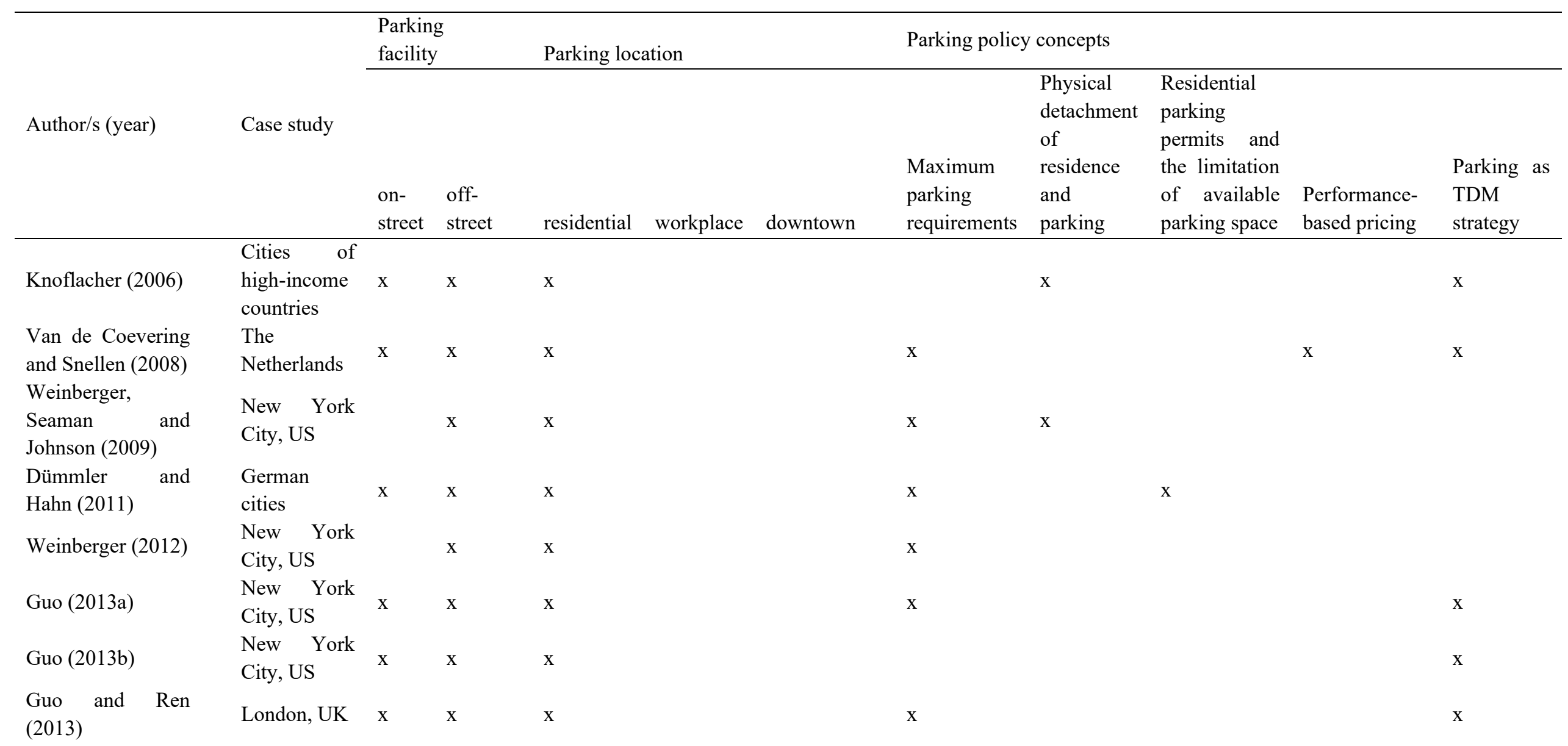


Ottosson, Chen,

Wang and Lin Seattle, US $\mathrm{x}$

(2013)

Axhausen,

Chikaraishi and

Hiroshima,

Japan

$\mathrm{x}$

$\mathrm{X}$

Mintsis, Taxiltaris,

Basbas and Stathis

Thessaloniki,

Greece

$\mathrm{X}$

$\mathrm{x}$

$\mathrm{x}$

Antonsson, Hrelja

and Henriksson

Gothenburg,

Sweden

Christiansen,

Engebretsen,

Fearnley and

Norway

(2017)

Christiansen,

Fearnley, Usterud

Norway

X 


\section{Discussion: Findings, challenges and policy implications}

In this section, we discuss the implications of the findings from the review for implementation in our case study of Frankfurt-Bornheim as a typical inner-city neighbourhood (table 2). While the results can be applied to similar neighbourhoods, the aim is to simulate how the policies from the review can be adapted for one example. We start with the two instruments for new housing developments, then we discuss the potentials for existing housing stock and we conclude with the need for parking as part of a broader TDM strategy.

\subsection{Instruments for new housing developments}

First, though the Hessian building code authorises municipalities to determine their regulations independently, with the exception of subsidised housing, the current parking regulations of the city of Frankfurt do not include maximum requirements. Instead, the regulations demand at least 1.5 parking spaces for detached and semi-detached houses. Reduced parking requirements for subsidised housing are a good starting point to extend this approach to all kinds of new housing developments. Subsequently, with decreased minimum standards, the amount of parking space built will decrease as well because developers tend to build only as much as is required by local authorities (Guo \& Ren, 2013). The local context and local politicians might perceive introducing maximum parking requirements as difficult, but with a long-term, convincing TDM strategy (see below) the acceptability for this type of policy can be increased (Van de Coevering \& Snellen, 2008).

Second, concerning the detachment of residential areas from off-street parking, current parking regulations allow a maximum distance of $300 \mathrm{~m}$ between a residence and parking only if a builder cannot provide all parking on the property of the development 
(City of Frankfurt, 2016). As suggested in the literature, the same walking distances from homes to parking locations (e.g. neighbourhood garages) and to public transport stations increase the attractiveness of public transport and decrease the usage of privately owned vehicles (Christiansen, Engebretsen et al., 2017; Christiansen, Fearnley et al., 2017; Knoflacher, 2006). In addition, the physical separation of residence and parking improves quality of life because it increases the number of pedestrians and reduces the amount of car trips in a neighbourhood. Local authorities could establish detachment as the standard case in their parking regulations and not as an exceptional one as it is today. Furthermore, the permitted walking distance from homes to parking space should be increased to up to $500 \mathrm{~m}$, which is defined as a feasible walking distance to public transport stations, according to the local transportation plan (City of Frankfurt \& TraffiQ, 2006).

\subsection{Instruments for existing housing stock}

Third, residential parking permits and limiting the availability of parking space enable local authorities to reduce the generation of car parking and use. Despite only operating publicly owned parking spaces but not private ones, improved parking management might affect parking provision in a neighbourhood. As the amount of parking permits issued is within the municipality's jurisdiction, by enacting stricter requirements, the local authority can reduce the number of parking permit holders in an area (Dümmler \& Hahn, 2011; Mintsis et al., 2016). At the same time, on-street parking might be reduced, partly moved to off-street parking in the form of a neighbourhood garage and the non-used onstreet parking areas might be used for other purposes.

Fourth, to introduce performance-based pricing on a supply-demand system, local authorities first have to initiate a legal pricing scheme for all of the existing public parking spaces. So far, parking off-street is more expensive in the neighbourhood than on-street parking because, in contrast to privately owned parking space, in most parts of the 
neighbourhood the publicly owned on-street parking space is free of charge and without time limits. In most German states, it is the municipalities' responsibility to regulate the pricing of parking and the parking charges can vary on a small scale. To date, the city of Frankfurt has two zones and a linear tariff for parking fees (Magistrat City of Frankfurt, 2013). To regulate parking space via pricing and not through a decrease in overall parking space may evoke criticism about the social aspect of this system. Yet, reducing on-street parking and varying parking fees spatially and temporarily could help public space to be used more efficiently, for instance, if parking was costly or more expensive at locations with high accessibility for other means of transportation during weekdays and close to shops, jobs and public transport stops. Still, the city could aim to incorporate both concepts by using a holistic approach towards urban parking (next section). To initiate performance-based pricing, a pilot project would be needed to be able to implement adjustments to the system later on and to communicate the concept of the pricing scheme. With increased parking revenue, the public transport, pedestrian and cycling infrastructure in the neighbourhood could then be improved (Axhausen et al., 2015; Ottosson et al., 2013). Furthermore, as part of the pricing scheme and to pursue a comprehensive approach, it would be plausible to change the pricing scheme for parking fines. The city could negotiate with the federal government for increased fees because currently parking fines are federally regulated and range between $10 €$ and $35 €(\mathrm{KBA}$, 2018), sometimes making it cheaper to pay a fine instead of a parking ticket.

\subsection{Parking as a TDM strategy}

Finally, fifth, a strategic vision on parking encompasses alternative modes, digital developments, communication and a mobility vision. The provision and promotion of alternatives to the private car (e.g. bicycle and pedestrian infrastructure, public transport, shared vehicles) form an important part of a municipality's strategy to reduce the need 
for private car parking. As the $\mathrm{HBO}$ allows municipalities to oblige builders to provide bicycle parking, the parking regulations of the city of Frankfurt include the provision of bicycle parking at ground level or with ramps. The regulations do not contain information about the number of bicycle parking spaces per dwelling and the kind of racks or facilities used, however. Therefore, it would be appropriate for municipalities to include bicycle parking as an integral element of local parking management (Klinger, Deffner, Kemen, Stein \& Lanzendorf, 2016). A further element to promote non-private car use is the provision of station-based carsharing. The allocation of parking space to shared vehicles can contribute to a reduction in the number of private vehicles. The city could change the then available space into, for instance, areas for urban gardening, local cafés, or bicycle parking to increase the quality of life in the neighbourhood regardless of one's car ownership. Subsequently, if the majority of existing parking space in a neighbourhood was off-street (neighbourhood garage) and not on-street, the quality of life would be increased further. Residents and visitors would have to walk through the neighbourhood to get to and from the garage as is the case for public transport users (Christiansen, Fearnley et al., 2017; Knoflacher, 2006). Although the literature shows that station-based carsharing has a relieving impact on urban mobility (Balac, Ciari \& Axhausen, 2017; Cervero, Golub \& Nee, 2007; Engel-Yan \& Passmore, 2013; Millard-Ball, Murray, Ter Schure, Fox \& Burkhardt, 2005; Schreier, Becker \& Heller, 2015), the share of carsharing members is still limited in Germany. Four percent of all households and 14\% of households in the main cities such as Frankfurt are carsharing members (Infas \& DLR 2018). The city could increase the attractiveness of carsharing by providing public parking space for this particular usage. The federal government has already issued the first carsharing act in Germany (Carsharinggesetz, CsgG) to allow public parking spaces to be designed for carsharing only (BMJV, 2017a). The city of Frankfurt is hesitant, 
however, because the state government of Hesse has still not changed its state road act (Hessisches Straßengesetz, HStrG) to provide a legal framework for municipalities.

Digital developments are both opportunities for and threats to the city's urban development and transportation goals, and, thus, accompanying policies are needed. For instance, the introduction of (1) parking guidance systems, (2) mobile parking and (3) shared parking in Frankfurt-Bornheim increase the convenience of parking and thus of car use. First, recently, intelligent parking guidance and information systems gained popularity (Pech, Jens, Warmuth \& Zeininger, 2006). Based on real-time data collection, intelligent parking systems (IPS) show drivers the availability and location of parking space or reserve parking space to reduce cruising time and search traffic that leads to traffic jams (Cao \& Menendez, 2018). We discern that an advantage of guidance systems is the release of search traffic and an increase in the quality of life in neighbourhoods located close to the city centre because the system will guide drivers to a free parking space in the city centre. This could turn into a rebound effect, however, when people decide to drive to the city centre, due to the convenience of being guided to free parking space. Second, mobile parking payment systems (MPPS) use information and communication technology (ICT), which makes it easier to pay for car drivers as they do not have to determine the maximum parking time beforehand. Municipalities can make use of it when they vary parking prices of public space by location and time of day, making current district-wide pricing redundant (Axhausen et al., 2015; Maternini, Ferrari \& Guga, 2017; Strauß, Urbanek \& Wörther, 2006). This may enforce the use of off-street parking, lead to a reduction in on-street parking space and provide options to reutilise onstreet parking space for other uses (Maternini et al., 2017). We conclude that, furthermore, MPPS allow municipalities to collect data about vehicle type and trip purpose. This is data that municipalities might use for better transportation demand management or to 
vary parking prices, depending on vehicles' land consumption and emissions. Third, eparking platforms offer the opportunity of shared use of private parking space that is otherwise not open to the public (Shao, Yang, Zhang \& Ke, 2016). For instance, companies can provide their parking space beyond their opening hours (e.g. Litman, 2016; Van de Coevering \& Snellen, 2008). We recognise that shared parking spaces increase their utilisation and make land use more effective by optimising the use of already existing parking space. The city might consider offering a sharing platform for parking as well to state the importance of more effective land use and to increase the pressure on private companies to open up their centrally located parking space. In addition, the municipality does not need to provide new parking space to retain the parking supply. To work with the developments, the city can introduce a citywide parking permit, a variable scheme for the pricing of parking and increase the prices to prevent car use from becoming more attractive due to digital development. Variable pricing schemes are probably only feasible in combination with mobile parking, however, which could start as a pilot project as well.

It should be kept in mind that the literature review reveals that parking policy concepts are not detached from each other but rather complement one another. For instance, the digital developments presented are connected to the regulations for parking requirements and performance-based pricing. Furthermore, a promotion of alternative means of transportation constantly increases the quality of life in a neighbourhood because such a promotion is accompanied by a redistribution of street space. Moreover, while each country, and often each city, has its own built environment legislative context due to local path dependencies, a municipality needs to have an overarching vision and a strategy towards urban parking (Guo, 2013a, 2013b). Otherwise, the local administration might get into conflict with local stakeholders and other interest groups if it does not 
communicate that parking is part of the city's TDM strategy. Communication is of importance, however, because the communication of policies to the general population and local stakeholders, such as retail and service providers, and their acceptance is a crucial issue for the success of parking policies (Dümmler \& Hahn, 2011; Mintsis et al., 2016). Therefore, with such a comprehensive strategy, the city of Frankfurt may increase the acceptance of its parking policy and, moreover, avoid spillover problems between neighbourhoods with different parking regulations (Antonson et al., 2017; Guo \& Ren, 2013).

Table 2. Type of parking policy, characteristics and legal framework for the implementation of more sustainable parking policies in Frankfurt-Bornheim.

\begin{tabular}{|c|c|c|}
\hline Parking policy type & Characteristics & Legal framework today \\
\hline \multicolumn{3}{|l|}{ For new housing developments } \\
\hline $\begin{array}{l}\text { 1. Maximum parking } \\
\text { requirements }\end{array}$ & $\begin{array}{l}\text { - Inclusion of maximum } \\
\text { requirements in parking regulations } \\
\text { for all kinds of housing } \\
\text { developments } \\
\text { - Reduction of minimum parking } \\
\text { requirements to decrease overall } \\
\text { parking space built }\end{array}$ & $\begin{array}{l}\text { Parking regulations of the city of } \\
\text { Frankfurt do not regulate maximum } \\
\text { requirements (exception: subsidised } \\
\text { housing) }\end{array}$ \\
\hline $\begin{array}{l}\text { 2. Physical detachment of } \\
\text { residence and parking }\end{array}$ & $\begin{array}{l}\text { - Obligation of separation into } \\
\text { parking regulations } \\
\text { - Neighbourhood garages }\end{array}$ & $\begin{array}{l}\text { Parking regulations of the city of } \\
\text { Frankfurt: max. distance } 300 \mathrm{~m} \text {, only if } \\
\text { builder cannot provide all parking on } \\
\text { property }\end{array}$ \\
\hline \multicolumn{3}{|l|}{ For existing housing stock } \\
\hline $\begin{array}{l}\text { 3. Residential parking permits } \\
\text { and the limitation of available } \\
\text { parking space }\end{array}$ & $\begin{array}{l}\text { - Stricter requirements for issuing } \\
\text { permits } \\
\text { - Turning on-street parking into off- } \\
\text { street parking }\end{array}$ & $\begin{array}{l}\text { - Municipality's competence to } \\
\text { implement parking permit zones }\end{array}$ \\
\hline 4. Performance-based pricing & $\begin{array}{l}\text { - Introduction of pricing scheme } \\
\text { - Introduction of varying fees } \\
\text { depending on location, day and time } \\
\text { - Changes to parking fines }\end{array}$ & $\begin{array}{l}\text { - Municipality's competence to } \\
\text { regulate parking fees } \\
\text { - Federal regulation about parking } \\
\text { fines }\end{array}$ \\
\hline \multicolumn{3}{|c|}{ Strategies to manage new developments and existing parking } \\
\hline 5. Parking as a TDM strategy & $\begin{array}{l}\text { - Fostering alternative means of } \\
\text { transportation } \\
\text { - Reutilisation of former parking } \\
\text { space } \\
\text { - Clear communication of goals } \\
\text { - Mobility vision for the city } \\
\text { - Introduction of digital } \\
\text { developments with policies }\end{array}$ & $\begin{array}{l}\text { - Parking regulations of the city of } \\
\text { Frankfurt make bicycle parking } \\
\text { obligatory } \\
\text { - Federal carsharing act - } \\
\text { implementation at local level pending } \\
\text { - Responsibility of the city of } \\
\text { Frankfurt to adjust pricing scheme }\end{array}$ \\
\hline
\end{tabular}




\begin{tabular}{|l|l|l|}
\hline & $\begin{array}{l}\text { preventing spillover effects and } \\
\text { increase of parking convenience }\end{array}$ & $\begin{array}{l}- \text { Mobile parking: legal framework } \\
\text { missing }\end{array}$ \\
\hline
\end{tabular}

\section{Conclusions}

The aim of this paper was to assess how the parking policy of a central urban neighbourhood can contribute to a more sustainable mobility system and increase liveability in the neighbourhood. We wanted to evaluate existing parking policy options, what is known about their expected and evaluated impacts, and what challenges might arise for the realisation of parking policies in a neighbourhood. Therefore, we reviewed literature about parking in urban, residential neighbourhoods and applied the findings to a typical inner-city neighbourhood.

First, we identified five parking policies from the existing literature: (i) maximum parking requirements as a tool for municipalities to regulate the amount of parking space built for new developments, (ii) the physical detachment of residence and parking space to reduce car use and make non-motorised means of transportation more attractive, (iii) residential parking permits for municipalities to limit the availability of public parking space, (iv) performance-based pricing varying parking fees temporarily and spatially, and (v) understanding parking as a transportation demand management strategy that includes a comprehensive approach towards parking using tools such as alternative means of transportation, reutilisation of parking space and digital developments. The review showed that parking and parking requirements in urban neighbourhoods are one key element to manage motorised private transport in the whole city. The literature reveals that the location and availability of parking have an impact on households' car ownership and usage and, therefore, on sustainable mobility. Moreover, the review indicates that municipalities need an integrated citywide strategy towards parking. 
Second, challenges from the legal framework, local implementation and digital developments are manifold. Regarding the national legal framework in Germany, the federal level has assigned the management of local parking regulations to the states (Bundesländer), which passed on these regulations to the municipalities. Yet, in certain cases, the municipalities are still dependent on the federal pricing and regulatory frameworks. For example, the municipalities needed to wait for the federal carsharing act to allocate public parking space to carsharing.

For local implementation, the results reveal that municipalities need to understand parking as a tool of transportation demand management, which they can use for their own good. For instance, even though the municipalities cannot control private parking space, they can try to exercise the influence they do have more via limiting public parking space and strengthening alternative means of transportation. In the German case, as in most other countries, states and municipalities need to redesign their legal frameworks to be able not only to manage car parking supply better, but, for example, to integrate bicycle parking as well. In the case of Frankfurt, the municipality acts hesitantly to avoid complaints from local residents and businesses. Instead, the city should not only implement improved parking policies, but, moreover, communicate their transport and urban development goals more openly to the public to get residents' support for new policies.

The review revealed that digital developments in parking are an opportunity for more sustainable mobility in urban neighbourhoods if they help to reduce the amount and convenience of on-street parking space. Moreover, municipalities may use digital developments to make varying pricing schemes feasible and collect data for better transportation demand management. Nevertheless, digital developments like intelligent 
parking guidance systems or mobile parking can easily turn into a threat to this objective if they make driving and parking in urban areas more convenient.

We applied the results from the literature review to the case study of FrankfurtBornheim as an example of a typical inner-city European neighbourhood. Even though there are specific regulations in each state and for each municipality, we believe the findings from the example are transferable to other similar neighbourhoods. It is noteworthy that although many of the instruments discussed are parking constraining measures, they may not limit overall accessibility. As inner-city neighbourhoods in many European cities are usually well connected to adjacent areas and to their city centres by public transportation and bicycle infrastructure, accessibility for urban destinations remains high. Thus, reduced space and accessibility for private cars lead to increased accessibility for non-motorised means of transportation and create space for other purposes. Hence, municipalities need to balance the different requirements of public urban space.

For further research, it should be noted that our sample of reviewed literature was limited to 14 papers only. We discovered that only a small number of papers regarding parking in urban neighbourhoods connects parking with sustainable mobility. In addition, to the best of our knowledge, very rarely studies addressed the effects of parking on the quality of life in neighbourhoods. The literature lacks a greater variety of research in this respect as most studies are limited to economic assumptions of parking policies. Despite Weinberger et al. (2009) conclude that parking management is an important tool for air quality management and Van de Coevering and Snellen (2008) address the issue by writing that illegally parked cars can affect green areas, they do not discuss liveability in detail. Furthermore, Melia (2015) stresses the importance of assessing the quality of the environment from a pedestrian viewpoint to encourage modal shift and to make cities 
more attractive as places. In this line of thought, Mintsis et al. (2016) propose incorporating residents more actively in decision-making processes. Hence, we conclude that we need further investigations into the complex relationships between residential parking and the quality of life in urban neighbourhoods.

\section{Note}

1. We understand carsharing as "short-term auto access" (Shaheen \& Cohen, 2007, p. 81).

\section{Acknowledgements}

This research was funded by the German Ministry of Education and Research for the project "QuartierMobil: Persistence and dynamics within the urban neighbourhood - Strategies for the future of urban mobility" under Grant number 01UR1702A. We would like to thank Jens Wöbbeking, Thomas Klinger and Sina Selzer for their critical comments, and Alison Hindley Chatterjee for the English language check.

\section{Disclosure statement}

No potential conflict of interest was reported by the authors.

\section{Funding}

This research was funded by the German Ministry of Education and Research for the project "QuartierMobil: Persistence and dynamics within the urban neighbourhood - Strategies for the future of urban mobility" under [grant number 01UR1702A].; Bundesministerium für Bildung und Forschung

\section{ORCID}

Franziska Kirschner http://orcid.org/0000-0002-6500-7794

Martin Lanzendorf http://orcid.org/0000-0003-3465-7695 


\section{References}

Antonson, H., Hrelja, R. \& Henriksson, P. (2017). People and parking requirements: Residential attitudes and day-to-day consequences of a land use policy shift towards sustainable mobility. Land Use Policy, 62, 213-222.

Apel, D., Henckel, D., Bunzel, A., Floeting, H., Henkel, M. J., Kühn, G., ... Sander, R. (1995). Flächen sparen, Verkehr reduzieren. Möglichkeiten zur Steuerung der Siedlungs- und Verkehrsentwicklung. [Saving land, reducing traffic. Possibilities for managing housing and traffic development]. Berlin: Difu.

Axhausen, K. W., Chikaraishi, M. \& Seya, H. (2015). Parking - Learning from Japan. Arbeitsberichte Verkehrs- und Raumplanung: Vol. 1095. Zurich: Eidgenössische Technische Hochschule Zürich.

Balac, M., Ciari, F. \& Axhausen K. W. (2017). Modelling the impact of parking price policy on free-floating Carsharing: Case study of Zurich, Switzerland. Transportation Research Part C, 77, 207-225.

Caicedo, F. (2012). Charging parking by the minute: What to expect from this parking pricing policy? Transport Policy, 19, 63-68.

Cao, J. \& Menendez, M. (2018). Quantification of potential cruising time savings through intelligent parking services. Transportation Research Part A, 116, 151-165.

Cervero, R., Golub, A. \& Nee, B. (2007). City CarShare: Longer-term travel demand and car ownership impacts. Transportation Research Record: Journal of the Transportation Research Board, 1992, 70-80.

City of Frankfurt. (2013). Stadtgebiet und Flächennutzung [Urban area and land use]. Retrieved from https://www.frankfurt.de/sixcms/media.php/678/01 Stadtgebiet und F1\%C3\%

\section{A4che.pdf}

City of Frankfurt. (2016). Stellplatzsatzung der Stadt Frankfurt am Main [Parking regulations of the city of Frankfurt]. Retrieved from https://www.bauaufsichtfrankfurt.de/fileadmin/Downloads_alle/Rechtsgrundlagen_und_Satzungen/201 $7 \quad 02 \quad 01$ Stellplatzsatzung und Stellplatzzahlen.pdf

City of Frankfurt. (2018). Statistik aktuell. Einwohnerinnen und Einwohner in Frankfurt am Main am 30. Juni 2018 [Current statistics. Inhabitants in Frankfurt am Main $\begin{array}{lllll}\text { on } & 30 & \text { June } & \text { 2018]. }\end{array}$ 
https://www.frankfurt.de/sixcms/media.php/678/13 Bev\%C3\%B6lkerung_Halbj ahr2018.pdf

City of Frankfurt. (2019). Bewohnerparkausweis [Residential parking permit]. Retrieved from

https://www.frankfurt.de/sixcms/detail.php?id=2943\&_ffmpar[ id inhalt] $=5812$ $\underline{4}$

City of Frankfurt \& TraffiQ. (2006). 1. Fortschreibung des Nahverkehrsplanes der Stadt Frankfurt am Main: Überarbeitete Fassung, November 2006 [First update of the local transport plan of the city of Frankfurt: Revised version, November 2006]. Stadt Frankfurt am Main.

Chatman, D. G. \& Manville, M. (2014). Theory versus implementation in congestionpriced parking: An evaluation of SFpark, 2011-2012. Research in Transportation Economics, 44, 52-60.

Christiansen, P., Engebretsen, Ø., Fearnley, N. \& Usterud Hanssen, U. (2017). Parking facilities and the built environment: Impacts on travel behaviour. Transportation Research Part A, 95, 198-206.

Christiansen, P., Fearnley, N., Usterud Hanssen, U. \& Skollerud, K. (2017). Household parking facilities: relationship to travel behaviour and car ownership. Transportation Research Procedia, 25, 4185-4195.

Dale, S., Frost, M., Ison, S., Nettleship, K. \& Warren, P. (2017). An evaluation of the economic and business investment impact of an integrated package of public transport improvements funded by a workplace Parking Levy. Transportation Research Part A, 101, 149-162.

Dümmler, O. \& Hahn, O. (2011). Bewohnerparken - Aktueller Stand und Hinweise zur Anwendung [Residential parking - Current status and references for implementation]. In Bracher, T, Dziekan, K., Gies, J., Huber, F. Kiepe, F. Reutter, U., ... O. Schwedes (Eds.) Handbuch der kommunalen Verkehrsplanung: Vol. 61. Berlin: Wichmann Verlag.

Engel-Yan, J. \& Passmore, D. (2013) Carsharing and car ownership at the building scale. Examining the potential for flexible parking requirements. Journal of the American Planning Association, 79(1), 82-91.

Federal Ministry of Justice and Consumer Protection. (2017a). Gesetz zur Bevorrechtigung des Carsharing (Carsharinggesetz - CsgG) [Act for 
prioritisation of carsharing (Carsharing act)]. Retrieved from https://www.gesetze-im-internet.de/csgg/BJNR223000017.html

Federal Ministry of Justice and Consumer Protection (BMJV). (2017b). Straßenverkehrsgesetz (StVG) [Road traffic regulations act]. Retrieved from https://www.gesetze-im-internet.https://www.gesetze-im-internet.de/stvg/

Federal Ministry of Justice and Consumer Protection (BMJV). (2017c). StraßenverkehrsOrdnung (StVO) [Road traffic act]. Retrieved from https://www.gesetze-iminternet.de/stvo_2013/

Guo, Z. (2013a). Does residential parking supply affect household car ownership? The case of New York City. Journal of Transport Geography, 26, 18-28.

Guo, Z. (2013b). Home parking convenience, household car usage, and implications to residential parking policies. Transport Policy, 29, 97-106.

Guo, Z. \& Ren, S. (2013). From minimum to maximum: Impact of the London parking reform on residential parking supply from 2004 to 2010?. Urban Studies, 50(6), 1183-1200.

Heinrichs, E. \& Schreiber, M. (2016). Kommunale Stellplatzsatzungen [Municipal parking regulations]. In Bracher, T., Dziekan, K., Gies, J., Huber, F., Kiepe, F., Reutter, U., ... O. Schwedes (Eds.) Handbuch der kommunalen Verkehrsplanung: Vol. 76. Berlin: Wichmann-Verlag.

Inci, E. (2015). A review of the economics of parking. Economics of Transportation, 4, 50-63.

Infas \& Deutsches Zentrum für Luft- und Raumfahrt (DLR). (2018). Mobilität in Deutschland. Kurzreport - Verkehrsaufkommen - Struktur - Trends [Mobility in Germany. Short report - Traffic volume, structure, trends]. Bonn: Bundesministerium für Verkehr und digitale Infrastruktur.

Federal Motor Transport Authority (KBA). (2018). Bundeseinheitlicher Tatbestandskatalog - Straßenverkehrsordnungswidrigkeiten [Federal facts catalogue - adverseness of road traffic act]. Retrieved from https://www.kba.de/DE/ZentraleRegister/FAER/BT_KAT_OWI/btkat_node.htm 1

Jalali, S. \& Wohlin, C. (2012, September). Systematic literature studies: Database searches vs. backward snowballing. Paper presented at the International Symposium on Empirical Software Engineering and Measurement, ESEM'12: Lund, Sweden. 
Khreis, H., Warsow, K. M., Verlinghieri, E., Guzman, A., Pellecuer, L., Ferreira, A., ... Nieuwenhuijsen, M. (2016). The health impacts of traffic-related exposures in urban areas: Understanding real effects, underlying driving forces and coproducing future directions. Journal of Transport \& Health, 3, 249-267.

Klinger, T., Deffner, J., Kemen, J., Stein, M. \& Lanzendorf, M. (2016). Sharing-Konzepte für ein multioptionales Mobilitätssystem in Frankfurt Rhine-Main. Analyse neuerer Entwicklungen und Ableitung von Handlungsoptionen für kommunale und regionale Akteure [Sharing concepts for a mulitoptional mobility system in FrankfurtRhein Main. Analysis of novel developments and conclusions for courses of action for municipal and regional actors]. Arbeitspapiere zur Mobilitätsforschung: Vol. 9. Frankfurt am Main: Goethe Universität Frankfurt.

Knoflacher, H. (2006). A new way to organize parking: the key to a successful sustainable transport system for the future. Environment \& Urbanization, 18(2), 387-400.

Land Hessen. (2018a). Hessische Bauordnung (HBO) [Hessian building code]. Retrieved from

http://www.rv.hessenrecht.hessen.de/lexsoft/default/hessenrecht rv.html?doc hl $=1 \& \mathrm{doc} \mathrm{id}=\mathrm{jlr}-$

$\underline{\text { BauOHE2010rahmen\&documentnumber=1\&numberofresults=106\&showdocca }}$ $\underline{\text { se }=1 \& \text { doc part=R\&paramfromHL }=\text { true\#docid:8081002,1,20180707 }}$

Land Hessen. (2018b). Hessisches Straßengesetz (HstrG) [Hessian road act]. Retrieved from

https://www.rv.hessenrecht.hessen.de/lexsoft/default/hessenrecht_rv.html?pid= Dokumentanzeige\&showdoccase $=1 \&$ js peid $=$ Trefferliste\&documentnumber $=1$ \&numberofresults $=72 \&$ from $\operatorname{loctodoc}=$ yes $\&$ doc $. i d=\mathrm{jlr}-$ StrGHErahmen\%3Ajuris$\underline{\text { 1r00\&doc } . \text { part }=X \& \text { doc } . \text { price }=0.0 \& \text { doc } \cdot h l=1 \# \text { docid: } 169958,1,20180607}$

Leclerc, F. (2017, October 17). Per App zum Parkplatz [Via app to the car park]. Frankfurter Rundschau. Retrieved from http://www.fr.de

Leclerc, F. (2018, August 24). Bewohnerparken ohne Zuwachs [No growth in residential parking]. Frankfurter Rundschau. Retrieved from http://www.fr.de

Lehmbrock, M. (2000). Straßennutzung und Stellplatzpflicht: Zur Entwicklung öffentlicher Räume mit vielfältigen Nutzungschancen. Berlin: Difu.

Litman, T. (2016). Parking management: Strategies, Evaluation and Planning. Victoria, BC: Victoria Transport Policy Institute. 
Magistrat City of Frankfurt. (2013). Vorlage M 203 [Template M 203]. Retrieved from https://www.stvv.frankfurt.de/download/M 203 2013.pdf

Marsden, G. (2006). The evidence base for parking policies - a review. Transport Policy, 13, 447-457.

Marsden, G. (2014). Parking Policy. In Ison, S. \& C. Mulley (Eds.) Parking: Issues and Policies (pp. 11-32). Bingley: Emerald.

Maternini, G., Ferrari, F. \& Guga, A. (2017). Application of variable parking pricing techniques to innovate parking strategies. The case study of Brescia. Case Studies on Transport Policy, 5, 425-437.

Melia, S. (2015). Urban transport without the hot air: Vol. 1: Sustainable solutions for UK cities. Cambridge, UK: UIT.

Millard-Ball, A., Murray, G., Ter Schure, J., Fox, C. and Burkhardt, J. (2005) CarSharing: Where and how it succeeds (Report No. 108). Washington, D.C: Transit Cooperative Research Program of the Transportation Research Board.

Mingardo, G., Van Wee, B. \& Rye, T. (2015). Urban parking policy in Europe: A conceptualization of past and possible future trends. Transportation Research Part A, 74, 268-281.

Mintsis, G., Taxiltaris, C., Basbas, S. \& Stathis, Y. (2016). Evaluation of the parking permits scheme for residents in Thessaloniki, Greece. In Liu, Y.-M., Fu, D., Tong, Z.-X., Bao, Z.-Q. \& B. Tang (Eds.) Civil Engineering and Urban Planning IV (pp. 37-43). London, UK: CRC Press.

Notz, J. N. (2017). Die Privatisierung des öffentlichen Raums durch parkende Kfz. Von der Tragödie einer Allmende - über Ursache, Wirkung und Legitimation einer gemeinwohlschädigenden Regulierungspraxis [The privatisation of public space through parked cars. About the tragedy of commons - cause, effect and legitimacy of a regulations practice that harms a public good]. IVP-Discussion Paper, 2017(1). Berlin: Technische Universität Berlin.

Ottosson, D. B., Chen, C., Wang, T. \& Lin, H. (2013). The sensitivity of on-street parking demand in response to price changes: A case study in Seattle, WA. Transport Policy, 25, 222-232.

Parkhurst, G. \& Meek, S. (2014). The effectiveness of park-and-ride as a policy measure for more sustainable mobility. In Ison, S. \& C. Mulley (Eds.) Parking: Issues and Policies (pp. 185-211). Bingley: Emerald. 
Pech, A., Jens, K., Warmuth, G. \& Zeininger, J. (2006). Parkhäuser - Garagen: Grundlagen, Planung, Betrieb. Vienna: Springer.

Pierce, G. \& Shoup, D. (2013), Getting the prices right. An evaluation of pricing parking by demand in San Francisco. Journal of the American Planning Association, 79(1), 67-81.

Rye, T. \& Koglin, T. (2014). Parking Management. In Ison, S. \& C. Mulley (Eds.) Parking: Issues and Policies (pp. 157-184). Bingley: Emerald.

Rye, T., Cowan, T. \& Ison, S. (2006). Expansion of a controlled parking zone (CPZ) and its influence on modal split: The case of Edinburgh. Transportation Planning and Technology, 29(1), 75-89.

Schreier, H., Becker, U. \& Heller, J. (2015). Evaluation CarSharing: Landeshauptstadt München [Evaluation Carsharing: State capital Munich]. Berlin.

Shaheen, S. A. \& Cohen, A. P. (2007). Growth in worldwide carsharing: An international comparison. Transportation Research Record: Journal of the Transportation Research Board, 1992, 81-89.

Shao, C., Yang, H., Zhang, Y. \& Ke, J. (2016). A simple reservation and allocation mode of shared parking lots. Transportation Research Part C, 71, 303-312.

Shoup, D. C. (2005). The high cost of free parking. Chicago: Planers Press - American Planning Association.

System repräsentativer Verkehrsbefragungen (SrV). (2013). Mobilitätssteckbrief für Frankfurt am Main - Mittlerer Werktag - (Wohnbevölkerung) [Mobility profile of Frankfurt am Main - Average working day - (resident population)]. Dresden: Technische Universität Dresden.

Strauß, C., Urbanek, M. \& Wörther, G. (2006, September). M-Parking - Mobile Parking Payment Systems in Europe. In Haasis, H.-D., Kopfer, H. \& J. Schönberger (Eds.) Operations Research Proceedings 2005: Selected Papers of the Annual International Conference of the German Operations Research Society (pp. 551556) Berlin: Springer.

Urry, J. (2004). The 'System' of Automobility. Theory, Culture \& Society, 21(4/5), 2539.

Van de Coevering, P. \& Snellen, D. (2008). The future of residential parking in The Netherlands: The impact of increasing car ownership on the character of residential areas. European Transport Conference 2008, Proceedings. Association for European Transport and contributors. 
Van der Waerden, P., Timmermanns, H. \& Da Silva, A. N. R. (2015). The influence of personal and trip characteristics on habitual parking behaviour. Case Studies on Transport Policy, 3, 33-36.

Van Ommeren, J., Wentink, D. \& Dekkers, J. (2011). The real price of parking policy. Journal of Urban Economics, 70, 25-31.

Verwaltungsgericht (VG, administrative court) Wiesbaden. (2018). Fahrverbot für Frankfurt am Main [Driving bans for Frankfurt am Main]. Retrieved from https://verwaltungsgerichtsbarkeit.hessen.de/pressemitteilungen/fahrverbotf\%C3\%BCr-frankfurt-am-main

Verwaltungsgericht (VG, administrative court) Frankfurt am Main. (2004). Urt. v. 18.02.2004, Az.:12 E 2659/03 [Decision of 18 February 2004, case no.: 12 E 2659/03].

Weinberger, R. (2012). Death by a thousand curb-cuts: Evidence on the effect of minimum parking requirements on the choice to drive. Transport Policy, 20, 93102.

Weinberger, R., Seaman, M. \& Johnson, C. (2009). Residential off-street parking impacts on car ownership, vehicle miles traveled, and related carbon emissions: New York City case study. Transportation Research Record: Journal of the Transportation Research Board, 2118, 24-30. 